\title{
Incidentally detected anomalous left atrial fibromuscular band
}

\author{
Mansi Verma ㄷ, ${ }^{1}$ Niraj Nirmal Pandey 다, ${ }^{1}$ Sanjeev Kumar, ${ }^{1}$ Rakesh Yadav ${ }^{2}$
}

'Department of Cardiovascular Radiology \& Endovascular Interventions, All India Institute of Medical Sciences, New Delhi, Delhi, India

${ }^{2}$ Department of Cardiology, All India Institute of Medical Sciences, New Delhi, Delhi, India

Correspondence to

Dr Sanjeev Kumar; sanjeevradio@gmail.com

Accepted 21 December 2021

\section{DESCRIPTION}

A 62-year-old man underwent coronary CT angiography for evaluation of suspected atherosclerotic coronary artery disease (CAD). While no obstructive CAD was noted, a unique left atrial anomaly was incidentally observed. A smooth hypodense fibromuscular band-like structure was noted within the left atrium, connecting the anteromedial and posterior walls of the left atrium and partially covering the right inferior pulmonary vein (RIPV) ostium (figures 1 and 2).

The left atrial band is a rare congenital anomaly with an incidence of $2 \%$ in autopsy studies. ${ }^{1}$ In most of the described cases, the band is seen connecting the left atrial aspect of the fossa ovalis with various areas of the left atrial endocardium. Various histopathological studies have demonstrated that these bands are composed of fibromuscular tissue. Although a benign

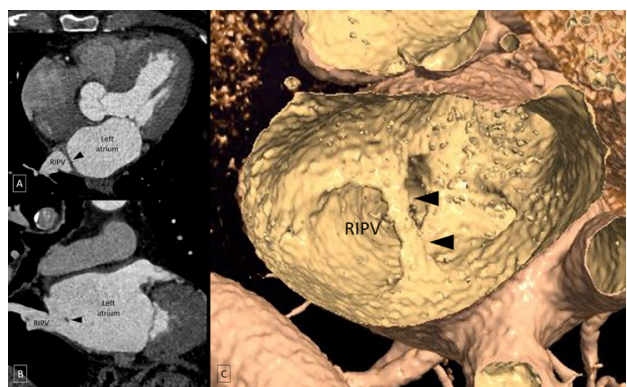

Figure 1 Oblique axial (A) and oblique coronal (B) images of CT angiography and virtual dissection image (C) show a smooth band-like structure (black arrowheads) within the left atrium, connecting its anteromedial and posterior walls, and partially covering the right inferior pulmonary vein (RIPV) ostium.
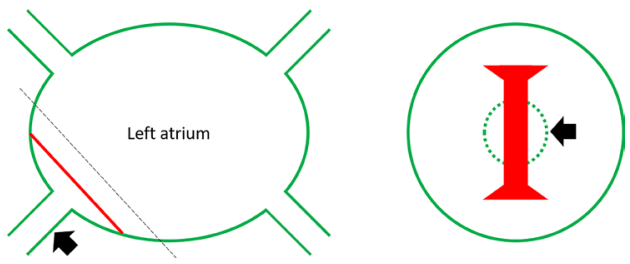

Limited 2022. No commercial re-use. See rights and permissions. Published by BMJ.

\begin{tabular}{|l|}
\hline To cite: Verma M, \\
Pandey NN, Kumar S, \\
et al.BMJ Case Rep \\
2022;15:e248402. \\
doi:10.1136/bcr-2021- \\
248402 \\
\hline
\end{tabular}

Figure 2 Schematic shows the smooth left atrial band (red line) connecting the anteromedial and posterior wall of the left atrium in relation to the right inferior pulmonary vein (RIPV) (thick black arrow) ostium. An en-face view from the plane of the dotted line shows the band partially covering the RIPV ostium (dotted green circle). (The figure is illustrated by N.N.P.)

\section{Learning points}

- Left atrial band is a rare congenital anomaly

- It is associated with the presence of Chiari network, premature atrial complexes, patent foramen ovale, mitral valve prolapse and regurgitation and episodes of cardioembolism.

- CT angiography plays an important role in the complete anatomical depiction of the left atrium and associated anomalies.

entity, it has potential clinical implications. It is associated with the presence of Chiari network, premature atrial complexes, patent foramen ovale, mitral valve prolapse and regurgitation and episodes of cardioembolism. ${ }^{12}$ The presence of the left atrial band, especially in relation to the pulmonary venous ostia as seen in the current case, can pose technical challenges during radiofrequency catheter ablation in the setting of atrial fibrillation. ${ }^{3}$ The present case highlights the role of CT angiography in the complete anatomical depiction of the left atrium and associated anomalies.

Contributors MV: prepared the manuscript. NNP: prepared the manuscript and images including the line diagram. SK: edited and proofread the manuscript. RY: edited and proofread the manuscript.

Funding The authors have not declared a specific grant for this research from any funding agency in the public, commercial or not-for-profit sectors.

Competing interests None declared.

Patient consent for publication Consent obtained directly from patient(s).

Provenance and peer review Not commissioned; externally peer reviewed.

Case reports provide a valuable learning resource for the scientific community and can indicate areas of interest for future research. They should not be used in isolation to guide treatment choices or public health policy.

ORCID iDs

Mansi Verma http://orcid.org/0000-0002-3313-4350

Niraj Nirmal Pandey http://orcid.org/0000-0001-6786-8304

\section{REFERENCES}

1 Yamashita T, Ohkawa S, Imai T, et al. Prevalence and clinical significance of anomalous muscular band in the left atrium. $A m$ J Cardiovasc Pathol 1993:4:286-93.

2 Ozer O, Sari I, Davutoglu V, et al. Cryptogenic stroke in two cases with left atrial band: coincidence or cause? Eur J Echocardiogr 2009;10:360-1.

3 Okajima K, Imamura K, Kanda G, et al. Left atrial anomalous muscular band detected by computed tomography before catheter ablation in a patient with atrial fibrillation. J Arrhythm 2015:31:64-5. 
Copyright 2021 BMJ Publishing Group. All rights reserved. For permission to reuse any of this content visit https://www.bmj.com/company/products-services/rights-and-licensing/permissions/

BMJ Case Report Fellows may re-use this article for personal use and teaching without any further permission.

Become a Fellow of BMJ Case Reports today and you can:

- Submit as many cases as you like

Enjoy fast sympathetic peer review and rapid publication of accepted articles

Access all the published articles

Re-use any of the published material for personal use and teaching without further permission

Customer Service

If you have any further queries about your subscription, please contact our customer services team on +44 (0) 2071111105 or via email at support@bmj.com.

Visit casereports.bmj.com for more articles like this and to become a Fellow 